Bangladesh J. Bot. 48(2): 297-306, 2019 (June)

\title{
STUDIES ON SOLANUM TORVUM SWARTZ ROOTSTOCK ON CULTIVATED EGGPLANT UNDER EXCESS MOISTURE STRESS
}

\author{
Sanjeev Kumar*, NB Patel and SN Saravaiya \\ Department of Vegetable Science, ASPEE College of Horticulture \& Forestry, \\ Navsari Agricultural University, Navsari-396 450, Gujarat, India
}

Key words: Solanum torvum, Grafting, Excess moisture stress, Shoot and fruit borer, Reproductive and Yield parameters

\begin{abstract}
A field experiment on grafting two cultivars of brinjal, namely Surati Ravaiya Pink and Surati Ravaiya Purple onto the rootstock of Solanum torvum Swartz was conducted to elucidate the influence on plant survival and other horticultural parameters under excess moisture stress. The results revealed 24.59 and $17.18 \%$ higher plant survival in grafts of Surati Ravaiya Pink and Surati Ravaiya Purple over their respective counter parts. Plant growth indicators like plant height and stem diameter showed significant increase in grafts over normal plants. Grafted plants were quite early in flowering taking 38.60 and 34.53 days in Surati Ravaiya Pink and Surati Ravaiya Purple, respectively which corresponded significantly for earliness in picking by more than 5 days. Grafting also regulated heterostyly polymorphism positively and significantly in both the cultivars resulting in higher fruit set in grafted plants. Higher number of fruits per plant and enhanced cropping period were also important yield contributing traits achieved through grafting. The grafted plants showed tolerance to shoot and fruit borer exhibiting 22.79 and $17.86 \%$ infestation in Surati Ravaiya Pink and Surati Ravaiya Purple, respectively. Economic parameters analysis revealed higher net returns in grafted plants compared to non-grafted ones.
\end{abstract}

\section{Introduction}

Brinjal or eggplant (Solanum melongena L.) is an important horticultural crop of Solanaceae family and widely cultivated in Asia, Africa, and subtropics (India, Central America), even in some warm temperate regions (Mediterranean area, South of the USA) (Sihachakr et al. 1993). Indo-Burma region being centre of origin for brinjal, presents significant variability for fruit shape (oval or egg-shaped to long club-shaped) and colour (white, yellow, green through degrees of purple pigmentation to almost purple black), thus signifies region specific choice among consumers for this crop in India. It is cultivated in an area of 0.67 million ha with annual production of 12.4 million tons in India (Anon. 2017). Brinjal is indicated for the treatment of several diseases like diabetes, arthritis, asthma and bronchitis. In addition, several groups have provided evidence that eggplant extracts have a significant effect in reducing blood and liver cholesterol rates in humans (Khan 1979, Jorge et al. 1998). Nasunin, a major component of anthocyanin pigment of eggplant, has been shown to inhibit lipid peroxidation (Igarashi et al. 1993). Free radical scavenging and iron chelating activities of nasunin were demonstrated by electron spin resonance (Noda et al. 2000).

However, susceptibility of brinjal to several diseases, pests, drought, flooding and others affects plant growth and development which causes serious yield losses. These biotic and abiotic problems have been addressed by hybridizing cultivated brinjal with wild resistant Solanum species. However, this approach is limited by sexual incompatibilities with wild relatives (Collonier et al. 2001) and difficulties in obtaining fertile progenies (Gleddie et al. 1986).

*Author for correspondence: <drsksony@nau.in>. 
Nowadays grafting is regarded as a rapid alternative tool to the relatively slow breeding methodology or incompatible crossing and has potential to increase tolerance of vegetables to various stresses (Flores et al. 2010). Cultivation of vegetable grafts permits not only pest resistance and high yields but also ameliorates crop losses caused by adverse environmental conditions. It has also been observed that grafting brinjal on wild species affects various physiological processes of a plant which in turn provide better opportunity to survive well and perform better in adverse climatic conditions. Grafting is a widespread technique used especially in cucurbitaceous and solanaceous vegetables (Minuto et al. 2007, Davis et al. 2008a, Oda 2007).

Though water is important for the plants but excess of water results in oxygen deficiency in the root zone and may cause hindrance in root respiration which lead to rotting and disease attack. These obstacles caused by excess of water availability or flooding can be fixed by grafting onto tolerant/resistant plant. Petran (2013) found that grafting tomato on Solanum torvum rootstock improved the flood tolerance and yield significantly.

South Gujarat region of the state in India falls under heavy rainfall zone and the people of the region have special preference for Surati Ravaiya type of brinjal cultivars for culinary purposes. However, cultivation of brinjal during rainy season faces various morphological and physiological stress on plant growth and development, thereby affects the plant stand and ultimately yield under such situations. High rainfall coupled with higher humidity limits the production of brinjal and leads to seasonality in its production.

Therefore, present investigation was aimed at getting benefit of grafting brinjal cultivars onto the rootstock of Solanum torvum Swartz for plant stand, heterostyly polymorphism, crop span, yield and tolerance of cultivated brinjal to shoot and fruit borer.

\section{Materials and Methods}

The investigation on grafting cultivated brinjal onto the rootstock of brinjal was carried out during Kharif, 2014, 2015 and 2016 at Regional Horticultural Research Station, Navsari Agricultural University, Navsari, Gujarat, India. The location is situated at a latitude of $20^{\circ} 57^{\prime} \mathrm{N}$ and longitude of $72^{\circ} 54^{\prime} \mathrm{E}$ with an altitude of $12 \mathrm{~m}$ amsl and falls under high rainfall zone.

Solanum torvum Swartz, a highly vigorous wild species of brinjal and tolerant to various biotic and abiotic stresses, was used as rootstock and Surati Ravaiya Pink and Surati Ravaiya Purple cultivars as scions. Cleft grafting technique was used to prepare grafts in each cultivar, which was performed in the afternoon after 4.00 p.m. onwards for better union and survival. Rootstock and scions were joined firmly with the help of grafting clips. Newly prepared grafts were first put in plug trays and then trays were shifted to water bath under polythene tunnel to initiate and fasten the healing process in grafts (Fig. 1). Relative humidly of more than $85 \%$ was maintained for better healing of grafts. After the completion of healing process, removal of grafting clips from grafts was followed by withholding water supply and the grafts were then removed from water bath for hardening. The grafts were ready for translating in 15 - 20 days (Figs $2,3)$.

The present experiment was arranged in 4 treatments consisting of grafted plants of both the cultivars and their non-grafted counterparts and laid out in RBD with 5 replicates accommodating 36 plants in each plot $(5.4 \times 3.6 \mathrm{~m})$ with a spacing of $90 \times 60 \mathrm{~cm}$. The experiment in each year was planned systematically in consideration with Agricultural Meteorological Cell, N.M. College of Agriculture, Navsari Agricultural University- Navsari so as to expose the treatments to natural submerged/water logged conditions in each year (Fig. 4.). Therefore, experiment was planted on 16 July, 2014, 25 July, 2015 and 27 July, 2016, which recorded $121 \mathrm{~mm}, 68 \mathrm{~mm}$ and $53 \mathrm{~mm}$ rainfall on the day of planting and subsequent days for exposing grafted and non-grafted plants to 
such conditions in each year of experimentation (Table 1). The recommended dose of fertilizers at the rate of 100: 50: 50 (NPK kg/ha) was applied to the crop, of which whole dose of $\mathrm{P}, \mathrm{K}$ and $1 / 2$ of $\mathrm{N}$ was given at time of planting. The remaining $\mathrm{N}$ was further split into 2 parts and applied at 30 and 60 days of planting.
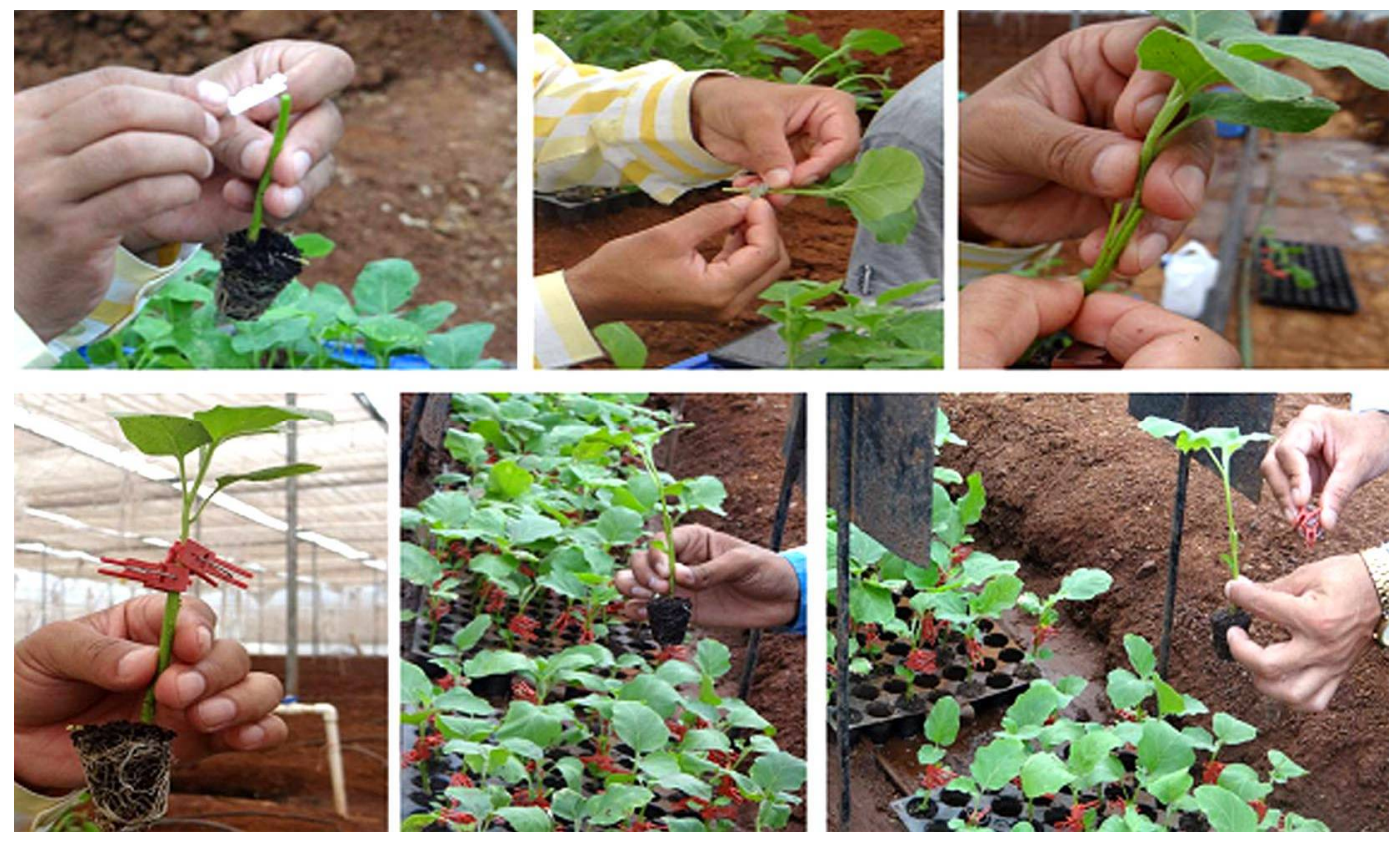

Fig. 1. Grafting procedure followed in the experiment.
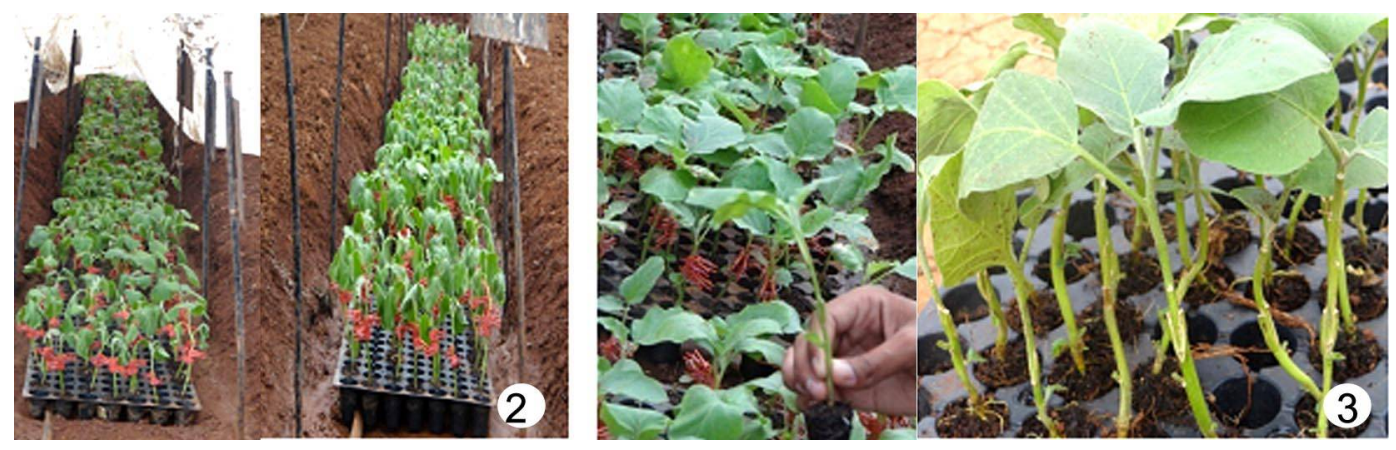

Figs. 2-3: 2. Healing of grafts in water bath under poly tunnel. 3. Revomal of grafting clip and hardeining of grafts.

The data on various parameters, namely plant survival $(\%)$, plant height $(\mathrm{cm})$, stem diameter $(\mathrm{cm})$, days to first flowering, picking, heterostyly polymorphism, fruit set $(\%)$, fruit length $(\mathrm{cm})$, fruit diameter $(\mathrm{cm})$, number of fruits per plant, total number of pickings, average fruit weight $(\mathrm{g})$, marketable yield and fruit infestation with shoot and fruit borer were recorded as per the standard procedures and the mean values were subjected to statistical analysis as per procedure laid down by Panse and Sukhatme (1985). The economic analysis of grafted vs. non-grafted brinjal was also carried out as per the methodology suggested by Subba et al. (2006). 

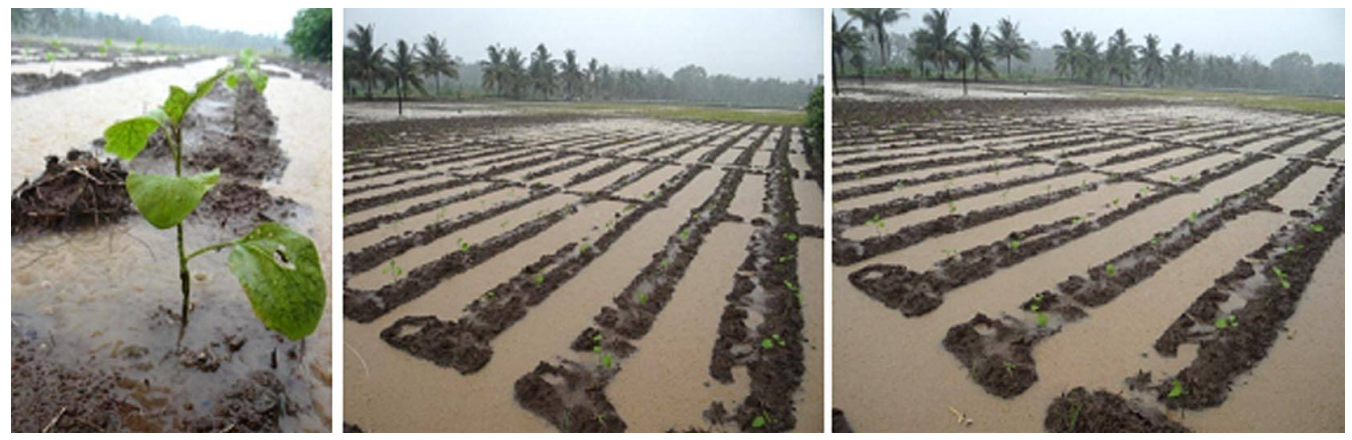

Fig. 4. Exposure of grafts and non-grafts of brinjal cultivars to submerged conditions during rainy season.

Table 1. Record of rainfall during years of experimentation.

\begin{tabular}{|c|c|c|c|}
\hline \multirow[t]{2}{*}{ Date } & Year 2014 & Year 2015 & Year 2016 \\
\hline & Rainfall (mm) & Rainfall (mm) & Rainfall (mm) \\
\hline 01 July & 0.0 & 0.0 & 25.0 \\
\hline $02 "$ & 14.0 & 0.0 & 34.0 \\
\hline $03 "$ & 0.0 & 0.0 & 108.0 \\
\hline $04 "$ & 1.0 & 0.0 & 26.0 \\
\hline $05 "$ & 0.0 & 0.0 & 6.0 \\
\hline 06 " & 0.0 & 1.0 & 1.0 \\
\hline 07 " & 0.0 & 1.0 & 1.0 \\
\hline 08 " & 6.0 & 0.0 & 0.3 \\
\hline $09 "$ & 24.0 & 0.0 & 9.0 \\
\hline $10 "$ & 2.0 & 5.0 & 1.0 \\
\hline $11 "$ & 2.0 & 1.0 & 5.0 \\
\hline $12 "$ & 0.4 & 0.5 & 2.0 \\
\hline $13 "$ & 10.6 & 0.0 & 0.2 \\
\hline $14 "$ & 1.0 & 0.0 & 3.0 \\
\hline $15 "$ & 0.5 & 0.0 & 3.5 \\
\hline $16 "$ & 121.0 & 0.5 & 5.0 \\
\hline $17 "$ & 5.5 & 3.0 & 4.0 \\
\hline 18 " & 19.0 & 0.0 & 19.0 \\
\hline $19 "$ & 74.0 & 5.0 & 14.0 \\
\hline 20 " & 1.0 & 21.0 & 22.0 \\
\hline $21 "$ & 0.0 & 1.5 & 18.0 \\
\hline $22 "$ & 1.0 & 39.0 & 1.0 \\
\hline $23 "$ & 1.0 & 25.5 & 3.0 \\
\hline $24 "$ & 79.0 & 19.0 & 1.0 \\
\hline $25 "$ & 11.0 & 68.0 & 0.0 \\
\hline $26 "$ & 2.0 & 22.0 & 2.0 \\
\hline $27^{\prime \prime}$ & 3.0 & 36.0 & 53.0 \\
\hline $28 "$ & 5.0 & 37.0 & 26.0 \\
\hline $29 "$ & 181.0 & 31.0 & 29 \\
\hline $30 "$ & 110.0 & 2.0 & 13 \\
\hline $31 "$ & 44.0 & 2.0 & 87 \\
\hline Total & 719.0 & 321.0 & 497.0 \\
\hline Mean & 23.2 & 10.4 & 16.6 \\
\hline
\end{tabular}

Source: Agricultural Meteorological Cell, N.M. College of Agriculture, Navsari Agricultural University, Navsari. 


\section{Results and Discussion}

The results of the present study indicated significantly higher survival percentage of grafts of Surati Ravaiya Pink as well as Surati Ravaiya Purple under submerged field conditions to the level of 96.67 and 97.78 , respectively exhibiting 24.59 and $17.18 \%$ higher plant stand compared to their non-grafted counterparts (Table 2). The better plant survival of grafted plants in both the cultivars in high intense rains during monsoon at Navsari expresses the suitability of Solanum torvum as rootstock to perform well under such conditions. A high moisture situation in the soil causes oxygen starvation and is often associated with so many soil borne problems like wilts, root knot nematodes etc. The vigorous root system of Solanum torvum and resistance to soil-borne diseases or pests, tolerance to abiotic stress, selective absorption of available soil nutrients confer a high degree of vigour to the scion (Lee and Oda 2003, Rivero et al. 2003, Davis et al. 2008b). Hu et al. (2006) have also suggested that improved nutrient uptake in grafted seedlings increases photosynthesis under week sunlight conditions and such conditions generally prevails during rainy season under South Gujarat conditions at Navsari.

The mean plant height among different treatments was also found to be significantly higher in grafted plants of both the cultivars. The grafts of Surati Ravaiya Pink showed a gain of $8.11 \%$ and Surati Ravaiya Purple 5.64\% compared to normal plants of respective cultivars. The comparative performance of grafted vs. non-grafted plants also showed significant differences for stem diameter exhibiting an increase of 2.81 and $5.64 \%$ in Surati Ravaiya Pink and Surati Ravaiya Purple, respectively (Table 2). Grafting had positive impact on plant vigour indicators like plant height and stem diameter thereby conferring the importance of rootstock in brinjal (Bletsos 2006, Khah 2011). Young (1989) has also suggested that vigorous root system of rootstock is often capable of absorbing nutrients more efficiently than scion roots. Leonardi and Giuffrida (2006) and Passam et al. (2005) have also indicated the different effect of grafting on plant height in respect of the combination of rootstock/brinjal varieties used.

Grafted plants showed significantly earliest in flowering taking 38.60 and 34.53 days in Surati Ravaiya Pink and Surati Ravaiya Purple, respectively compared to their counter parts (43.07 and 39.67 days). Thus earliness in flowering corresponded proportionally and significantly for days to first picking in both the cultivars. The grafted plants showed an earliness of more than 5 days in comparison to their analogues (Table 2). Though, grafts of each cultivar responded significantly but expressed variable response. Thus, such a variable response of these cultivars for earliness suggests the specificity of rootstock to cultivars influencing various physiological processes to enhance the reproductive ability of the crop (Bletsos 2003).

Grafting cultivated brinjal onto Solanum torvum regulated heterostyly polymorphism positively and significantly in both the cultivars. The overall percentage of long styled flowers was observed to be higher in grafted Surati Ravaiya Pink (38.22\%), while much higher percentage of such flowers (43.89) was noticed in grafted Surati Ravaiya Purple (Table 2). Consequently, the presence of significantly higher percentage of medium styled flowers in non-grafts was observed compared to grafts. Likewise, normal plants of both the cultivars showed higher percentage of pseudo short and true short styled compared to grafts (Table 2). Therefore, positive effect of grafting on heterostyly polymorphism was corresponded to fruit set percentage in both the cultivars under study. Grafted plants of Surati Ravaiya Pink and Surati Ravaiya Purple showed an overall fruit set of 69.69 and $72.37 \%$, respectively compared to their respective non-grafts (60.95 and $63.23 \%$ ) (Table 2). It has been well established that heterostyly polymorphism is an important phenomenon deciding extent of fruit set in brinjal (Handique and Sarma 1995, Passam and Bolmatis 1997, Kowalska 2006). Among various stylar levels in brinjal, long styled flowers shows high pollination as well as fruit set efficiency followed by medium styled flowers and so on (Chen 


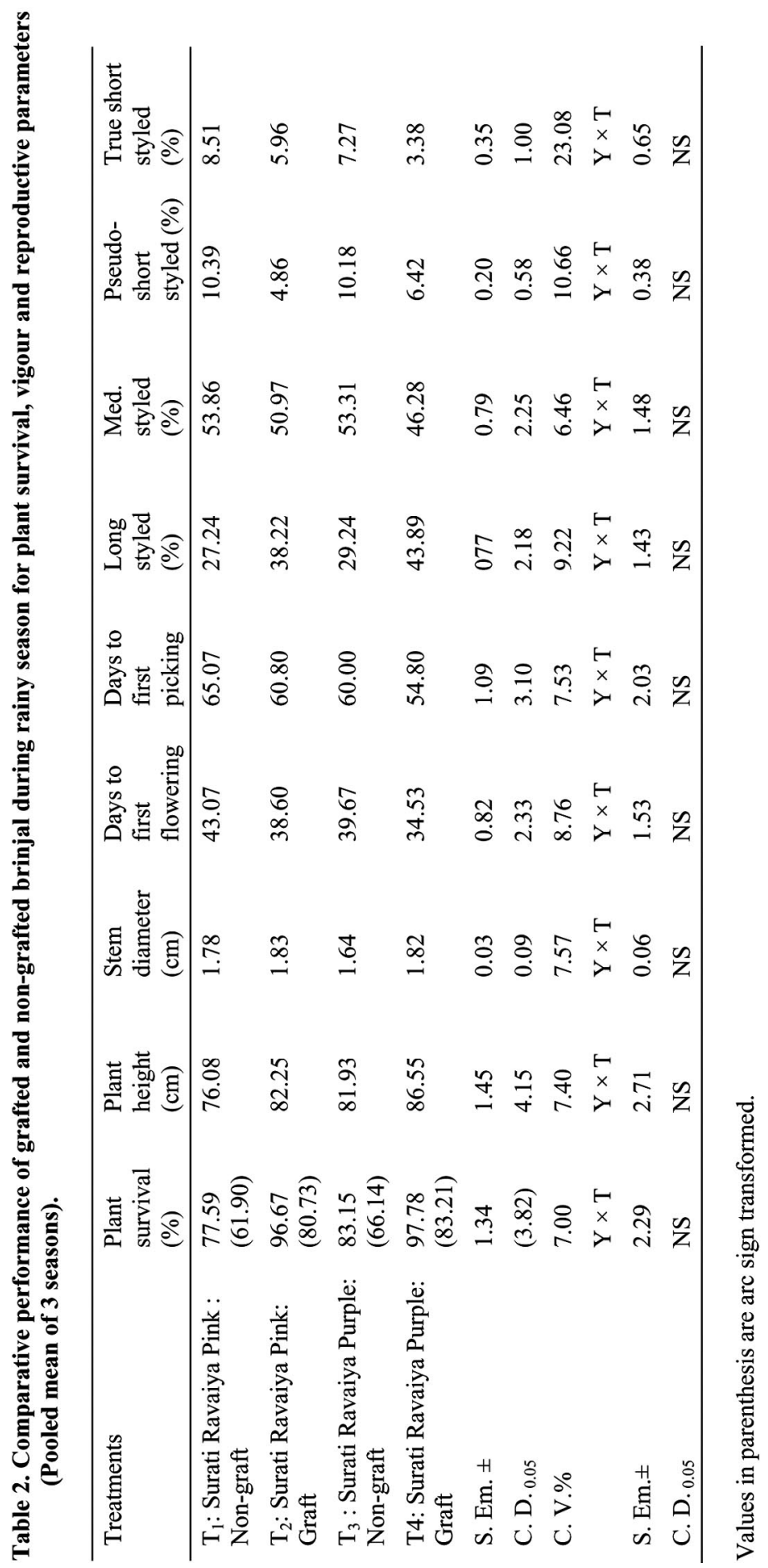




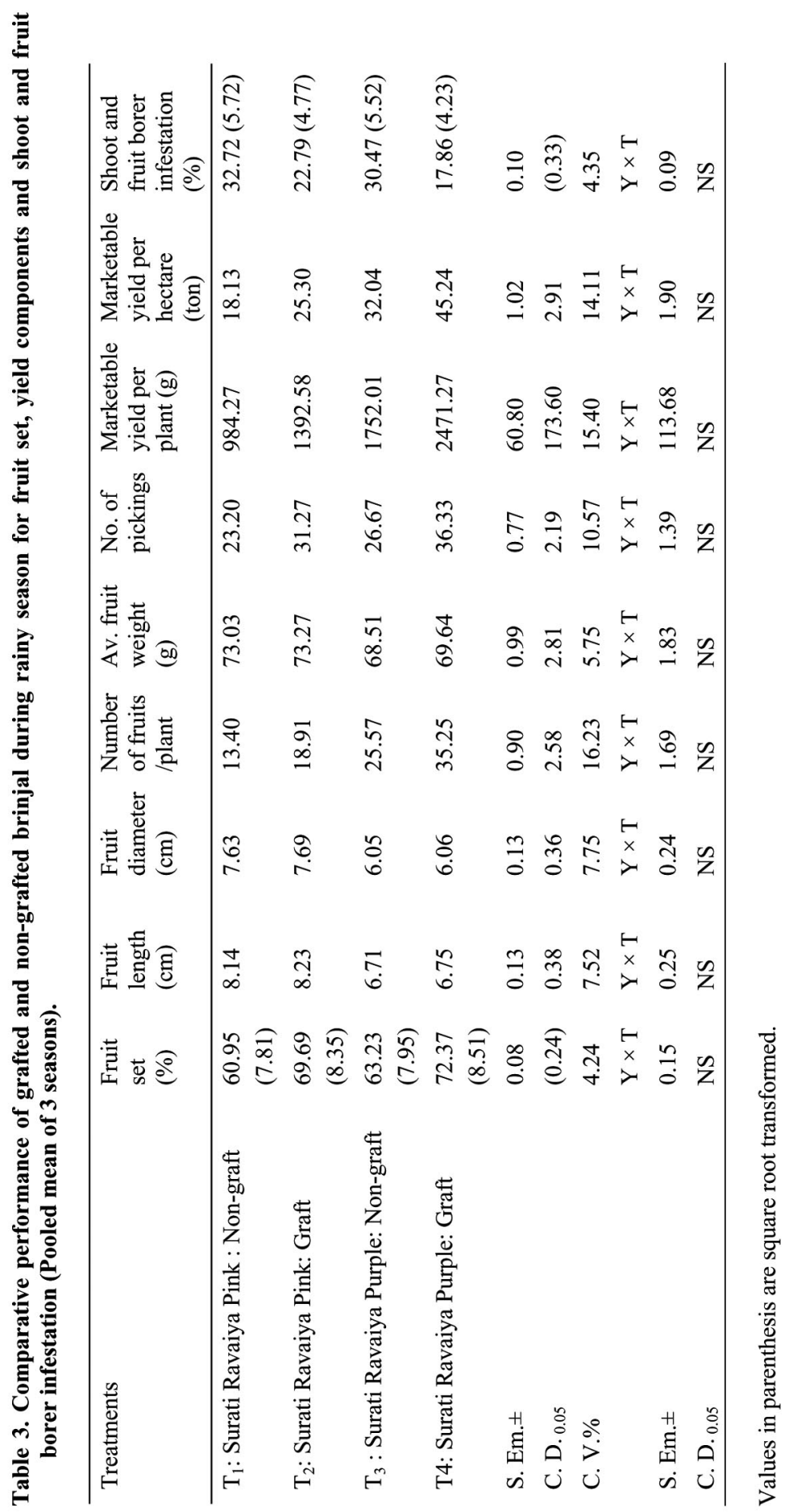


2001, Sekara and Bieniasz 2008). The presence of higher percentage of long styled flowers followed by medium styled flowers in grafted plants of both the cultivars reflects the ability of rootstock to bring changes in heterostyly. It is also supported by the findings of earlier workers (Zeevaart 1976, Mohamed et al. 2013) who stated that initiation of morphogenic changes in scions by grafting induce changes on leaves, flowers and fruits due to genetic changes highlighting its potential in genetic improvement.

It is evident from per se performance of all the treatments that grafted plants recorded higher average values for fruit length and diameter in both the cultivars. However, variations between grafted and non-grafted plants were observed to be non-significant. Grafted plants of Surati Ravaiya Pink produced significantly higher number of fruits with average value of 18.91 in comparison to non-grafts (13.40). The grafted plants of Surati Ravaiya Purple also showed similar trend producing 35.25 fruits compared to 25.57 in non-grafts. Grafting also exerted significant effect on crop duration resulting into higher number of pickings. Grafted plants of Surati Ravaiya Pink had an overall 31.27 pickings compared to non-grafted ones (23.20), while grafts of Surati Ravaiya Purple showed even more number of pickings (36.33) in comparison to 26.67 pickings in normal plants of this cultivar. However, performance of grafts vs. normal plants in both the cultivars did not show any significant difference for average fruit weight. Marketable yield per plant and hectare differed significantly over the years between grafted and non-grafted plants of both the cultivars. Marketable yield was 1392.58 g per plant and 21.81 tonnes per ha in grafted plants of Surati Ravaiya Pink compared to $984.27 \mathrm{~g}$ and 15.62 in non-grafted plants. Whereas, grafted plants of Surati Ravaiya Purple produced $2471.27 \mathrm{~g}$ yield per plant and 38.99 tonnes per ha in comparison to $1752.01 \mathrm{~g}$ and 27.61 tonnes in non-grafts (Table 3). The major yield contributing traits observed in grafted plants of both the cultivars were production of higher number of fruits per plant and enhancement of cropping span to take more number of harvests from these plants compared to non-grafted plants. This was also corroborated with the findings of Sabatino et al. (2013), Miceli et al. (2014) and. Hormonal signaling in rootstock-scion interactions might have a greater impact on flowering and fruit setting (Aloni et al. 2010). This increase in yield can also be related to higher vigorous growth of grafted plants and such response has also been observed by Leonardi and Giuffrida (2006) while studying the grafting effect of interspecific tomato rootstock on tomato.

Table 4. Comparative economic analysis of grafted vs. non-grafted brinjal.

\begin{tabular}{lllllll}
\hline Treatments & $\begin{array}{l}\text { Fruit } \\
\text { yield } \\
\text { (t/ha) }\end{array}$ & $\begin{array}{l}\text { Gross } \\
\text { realization } \\
\text { (Rs/ha) }\end{array}$ & $\begin{array}{l}\text { Cost A } \\
\text { (Variable cost }+\begin{array}{l}\text { Cost B } \\
\text { Interest on } \\
\text { working capital) }\end{array}\end{array}$ & $\begin{array}{l}\text { Cost } \mathrm{A}+ \\
\text { Rental value } \\
\text { of land) }\end{array}$ & $\begin{array}{l}\text { Cost } \\
\text { [Total cost of } \\
\text { cultivation } \\
\text { (Rs/ha) }\end{array}$ & $\begin{array}{l}\text { Net } \\
\text { (Rs/ha) }\end{array}$ \\
\hline $\begin{array}{l}\mathrm{T}_{1}: \text { Surati Ravaiya } \\
\text { Pink : Non-graft }\end{array}$ & 18.12 & 453000.00 & 133740.00 & 163940.00 & 163940.00 & 289060.00 \\
$\begin{array}{l}\mathrm{T}_{2}: \text { Surati Ravaiya } \\
\text { Pink: Graft }\end{array}$ & 25.30 & 632500.00 & 242312.00 & 284478.00 & 284478.00 & 348022.00 \\
$\begin{array}{l}\mathrm{T}_{3}: \text { Surati Ravaiya } \\
\text { Purple: Non-graft }\end{array}$ & 32.36 & 809000.00 & 135501.00 & 189434.00 & 189434.00 & 619566.00 \\
$\begin{array}{l}\text { T4: Surati Ravaiya } \\
\text { Purple: Graft }\end{array}$ & 45.23 & 1130750.00 & 245968.00 & 321352.00 & 321352.00 & 809398.00 \\
\hline
\end{tabular}

The tolerance of grafted plants to shoot and fruit borer was indicated by significantly less infestation. The overall infestation of $22.79 \%$ was observed in grafted plants of Surati Ravaiya Pink compared to $32.72 \%$, while grafted Surati Ravaiya Purple recorded $17.86 \%$ infestation in contrast to 30.47 in normal plants of the cultivar (Table 3). Less infestation in grafted plants of 
brinjal by brinjal shoot and fruit borer also confer to contribute towards yielding ability of grafted plants. Similar kind of response was also observed in eggplant cv. Epic upon grafting onto the rootstocks of Solanum lycopersicum $\times S$. habrochaites and $S$. aethiopicum by Johnson et al. (2014).

Economic analysis of grafted vs. non-grafted revealed that cost of planting material in grafted crop though was higher but net returns to the tune of Rs. 348022.00 and Rs. 809398.00 could be realized in grafted Surat Ravaiya Pink and Surat Ravaiya Purple, respectively in comparison to Rs. 289060.00 and Rs. 619566.00 in their non-grafted analogues (Table 4).

It can be concluded that grafting brinjal onto the rootstock of Solanum torvum Swartz provides better plant survival during rainy season, fruit set, comparatively less shoot and fruit borer infestation, extended crop period, higher yield and net returns.

\section{References}

Aloni B, Cohen R, Karni, L, Aktas H and Edelstein M 2010. Hormonal signaling in rootstock-scion interactions. Scientia Horticulturae 127: 119-126.

Anonymous 2017. Horticultural Statistics at a Glance 2017. Horticulture Statistics Division, Department of Agriculture,Cooperation \& Farmers Welfare, Ministry of Agriculture \& Farmers Welfare, Government of India. pp. 16.

Bletsos F 2003. Effect of grafting on growth, yield and Verticillium wilt of eggplant. Horticulture Science 38: $183-186$.

Bletsos F 2006. Grafting and calcium cyanamide as alternatives to methyl bromide for greenhouse eggplant production. Scientia Horticulturae 107: 325-331.

Chen NC 2001. Eggplant seed production. AVRDC, International Cooperators' Guide. Asian Vegetable Research and Development Center, Shanhua, Taiwan.

Collonier C, Fock I, Kashyap V, Rotino GL, Daunay MC, Lian Y, Mariska IK, Rajam MV, Servaes A, Ducreux G and Sihachakr D 2001. Applications of biotechnology in eggplant. Plant Cell, Tissue and Organ Culture 65: 91-107.

Davis AR, Perkins-Veazie P, Hassell R, Levi A, King SR and Zhang XP 2008b. Grafting effects on vegetable quality. Horticulture Science 43: 1670-1672.

Davis AR, Perkins-Veazie P, Sakata Y, Lopez-Galarza S, Maroto JV, Lee SG, Huh YC, Sun Z, Miguel A, King S, Cohen R and Lee JM 2008a. Cucurbit grafting. Critical Reviews in Plant Sciences 27: 50-74.

Flores FB, Sanchez-Bel P, Estan MT, Martinez-Rodriguez MM, Moyano E, Morales B, Campos JF, GraciaAbellan JO, Egea MI, Fernandeze-Garcia N, Romojaro F and Bolarin MC 2010. The effectiveness of grafting to improve tomato fruit quality. Scientia Horticulturae 125: 211-217.

Gleddie S, Keller W and Setterfield G 1986. Somatic embryogenesis and plant regeneration from cell suspension derived protoplasts of Solanum melongena (eggplant). Canadian Journal of Botany 64: 355361.

Handique AK and Sarma A 1995. Alteration of heterostyly in Solanum melongena L. through gammaradiation and hormonal treatment. Journal of Nuclear Agriculture and Biology 24: 121-126.

Hu CM, Zhu YL, Yang LF, Chen SF and Hyang YM 2006. Comparison of photosynthetic characteristics of grafted and own-root seedling of cucumber under low temperature circumstances. Acta Botany BorealOccident Sinica 26: 247-253.

Igarashi K, Yoshida T and Suzuki E 1993. Antioxidative activity of nasunin in chouja-nasu (little eggplant, Solanum melongena L. Chouja). Journal of the Japanese Society of Food Science and Technology 40(2): 138-143.

Johnson S, Inglis D and Miles C 2014. Grafting effects on eggplant growth, yield, and Verticillium wilt incidence. International Journal of Vegetable Science20 (1): 3-20. 
Jorge PAR, Neyra LC, Osaki RM, Almeida E and Bragagnolo N 1998. Efeito da berinjel asobreoslipides plasmaticos, a peroxidacaolipidica e a reversao da disfuncaoendotelialnahipercolesteromia experimental. ArquivosBrasileiros de Cardiologia70: 87-91.

Khah EM 2011. Effect of grafting on growth, performance and yield of aubergine (Solanum melongena L.) in greenhouse and open-field. International Journal of Plant Production 5: 1735-8043.

Khan R 1979. Solanum melongena and its ancestral forms. In: The Biology and Taxonomy of the Solanaceae, Hawkes J, Lester R and Skelding A (Eds), pp. 629-636. Academic Press, London.

Kowalska G2006. Eggplant (Solanum melongena L.) flowering and fruiting dynamics depending on pistil type as well as way of pollination and flower harmonization. Folia Horticulturae 18: 17-29.

Lee JM and Oda M 2003. Grafting of herbaceous vegetable and ornamental crops. Horticultural Reviews 28: $61-124$.

Leonardi C and Giuffrida F 2006. Variation of plant growth and macronutrient uptake in grafted tomatoes and eggplants on three different rootstocks. European Journal of Horticulture Science 71: 97-101.

Miceli A, Sabatino L, Moncada A, Vetrano F and D'Anna F 2014. Nursery and field evaluation of eggplant grafted onto unrooted cuttings of Solanum torvum Sw. Scientia Horticulturae 178: 203-210.

Minuto A, Minuto G, Bertetti D and Garibaldi A 2007. Attacks of Rhizoctoniasolani on tomato rootstocks in Italy. Informatore Fitopatologico 57: 44-46.

Mohamed TAE, Talaat D, Abdel Magid, Rudwan Mohammed Ahmed and Anas Ahmed Ibrahim 2013. Morphological changes on scions due to grafting eggplant and pepper Capsicum annuum (L.) onto tomato as rootstock. Journal of Forest Products and Industries 2: 30-35.

Noda Y, Kneyuki T, Igarashi K, Mori A and Packer L 2000. Antioxidant activity of nasunin, an anthocyanin in eggplant peels. Toxicology 148: 119-123.

Oda M 2007. Vegetable seedling grafting in Japan. Acta Horticulturae 759: 175-180.

Panse VG and Sukhatme PV 1985. Statistical Methods for Agricultural Workers. Indian Council of Agricultural Research, New Delhi, India.

Passam HC and Bolmatis A 1997. The influence of style length on the fruit set, fruit size and seed content of aubergines cultivated under high ambient temperature. Tropical Science 37: 221-227.

Passam HC, Stylianou M and Kotsiras A 2005. Performance of eggplant grafted on tomato and eggplant rootstocks. European Journal of Horticultural Science 70: 130-134.

Petran AJ 2013. Interspecific grafting of tomato (Solanum lycopersicum) onto wild eggplant (Solanum torvum) for increase environmental tolerances. M.Sc. Thesis, University of Minnesota, Minneapolis, USA.

Rivero RM, Ruiz JM and Romero L 2003. Role of grafting in horticultural plants under stress conditions. Journal of Food, Agriculture and Environment 1: 70-74.

Sabatino L, Palazzolo E and D'Anna F 2013. Grafting suitability of Sicilian eggplant ecotypes onto Solanum torvum: fruit composition, production and phenology. Journal of Food, Agriculture and Environment 11: 1195-1200.

Sekara A and Bieniasz M 2008. Pollination, fertilization and fruit formation in eggplant (Solanum melongena L.). Acta Agrobotanica 61: 107-113.

Sihachakr D, Chaput MH, Serraf I, Ducreux G 1993. Regeneration of plants from protoplasts of eggplant (Solanum melongena L.). In: Biotechnology in Agriculture and Forestry, vol. 23, Plant Protoplasts and Genetic Engineering IV, Bajaj YPS (Ed.), pp. 108-121. Springer, Berlin.

Subba Reddy S, Raghu Ram P, Sastry TVN and Bhavana Devi I 2006. Agricultural Economics. Oxford \& IBH Publishing Co. Pvt. Ltd., New Delhi. pp. 345-349.

Young E 1989. Cytokinin and soluble carbohydrate concentrations in xylem sap of apple during dormancy and bud break. Journal of the American Society for Horticultural Science 114: 297-300.

Zeevaart JAD 1976. Physiology of flower formation. Annual Review of Plant Physiology 27: 321-348.

(Manuscript received on 2 July, 2018; revised on 18 July, 2018) 